\title{
Rethinking the sulfur isotope record of the Paleoproterozoic Francevillian succession of Gabon
}

\author{
KÄRT PAISTE ${ }^{1,2}$, KAREN BAKAKAS MAYIKA ${ }^{3}$, DAVID \\ A. FIKE ${ }^{1}$, KALLE KIRSIMÄE ${ }^{2}$, ANTOINE CRÉMIÈRE ${ }^{4}$, \\ HELE-RIIN JUHKAMA ${ }^{2}$, R. SETH WOOD ${ }^{1}$, MATHIEU \\ MOUSSAVOU $^{3}$, TONY PRAVE ${ }^{5}$ AND AIVO LEPLAND ${ }^{6}$ \\ ${ }^{1}$ Washington University in St Louis \\ ${ }^{2}$ University of Tartu \\ ${ }^{3}$ Université des Sciences et Techniques de Masuku \\ ${ }^{4}$ Caltech \\ ${ }^{5}$ University of St Andrews \\ ${ }^{6}$ Geological Survey of Norway \\ Presenting Author: kart.paiste@ut.ee
}

The early Paleoproterozoic encompasses the postulated $\sim 2.3-$ 2.0 Ga Lomagundi-Jatuli Event (LJE), a large-scale positive carbonate $\mathrm{C}$-isotope $\left(\delta^{13} \mathrm{C}_{\text {carb }}\right)$ excursion believed to reflect transient oxygenation of otherwise poorly ventilated Paleoproterozoic oceans. The archetypal LJE-bearing Paleoproterozoic Francevillian succession of Gabon is typified by a sequence of ${ }^{13} \mathrm{C}$-enriched shallow-water carbonates, followed by black shales that carry unusually negative organic carbon $\left(\delta^{13} \mathrm{C}_{\text {org }}\right.$ of $\left.\sim-45 \%\right)$ and positive pyrite sulfur $\left(\delta^{34} \mathrm{~S}>\right.$ $+20 \%$ ) isotopic compositions. The opposing behavior of the $\delta^{13} \mathrm{C}_{\text {org }}$ and pyrite $\delta^{34} \mathrm{~S}$ records in the Francevillian $\mathrm{FB}-\mathrm{FC}$ interval of the reference lithostratigraphic column has been explained by decreasing seawater sulfate concentrations that allowed for enhanced methane cycling in the water column [1]. However, a recent sedimentological assessment of the relationship between facies and Francevillian $\mathrm{C}$-isotope profile challenges the popular opinion that the LJE archives global Ccycle disturbances and emphasizes placing stable isotope data into the sedimentological context [2].

Here we reevaluate the meaning of the $\mathrm{S}$ isotope record in the upper part of the Francevillian succession, by combining classical geological and novel geochemical approaches to investigate two LST12 $(139 \mathrm{~m})$ and Doumé $(76 \mathrm{~m})$ cores from the stratigraphic FB - FD interval. We demonstrate that the organic $\mathrm{C}$ and pyrite $\mathrm{S}$ isotope records are facies dependent, i.e., lower $\delta^{13} \mathrm{C}_{\text {org }}\left(\sim-47 \%\right.$ ) and pyrite $\delta^{34} \mathrm{~S}$ (typically $<5 \%$, down to $-13 \%$ ) values associate with deep-water facies, while $\delta^{13} \mathrm{C}_{\text {org }}(\sim$ $-27 \%$ ) and pyrite $\delta^{34} \mathrm{~S}(>5 \%$, up to $46 \%$ ) become higher in the shallow-water facies. Additionally, the presence of multiple pyrite textures, e.g., small framboidal and large zoned pyrites, indicate that the ${ }^{34} \mathrm{~S}$ enriched pyrites more likely reflect porewater conditions rather than changes in the seawater sulfate pool. These results are inconsistent with the canonical view of early Paleoproterozoic environmental change and demonstrate that basin-specific conditions strongly influenced the Francevillian Cand $\mathrm{S}$-isotope records.

[1] Ossa-Ossa et al. (2018), EPSL 486, 70-83.

[2] Bakakas Mayika et al. (2020), Geology 48, 1099-1104. 